\title{
ECONOMIC SPATIAL MODELING OF EGER AND MISKOLC ON MAPS WITH DIFFERENT GIS METHODS
}

\author{
Bence Czímer - Balázs Magyar - Csaba Ruszkai
}

\begin{abstract}
:
In this study we did the economic spatial modeling of the cities of Eger and Miskolc on maps with different GIS methods. The aim was to produce maps that accurately display the nodes and the operating time interval of companies in different national economic sectors within a given city. The geo-referencing of the available settlement planning maps was necessary for the city of Miskolc. Both GIS and enterprise database building are required to produce the aforementioned results, for which we have used various software and methods.
\end{abstract}




\section{Introduction}

During the research we worked on the economic spatial modeling of Eger and Miskolc in a GIS system. We used several methods to illustrate the spatial distribution of firms within cities: building-based and district-level visualization techniques. This required the creation of a geographic information system and an entrepreneurial database, with the help of these we could create various thematic maps based on the data of the companies. The different methodological structure of the economic map of the two cities was needed due to the availability of data and settlement development plans. By comparing the two databases, it is possible to observe the concentration of the nodes of the companies operating in the selected city, as well as the areas where more companies are established and the period of their operation.

\section{Methods}

\section{Creating the map of Miskolc}

The inner city of Miskolc consisted of 84 section of settlement organizing map in vector pdf format, which we obtained from the official website of the city. To begin georeferencing, we converted these files to $\mathrm{dwg}$. extensions that is compatible with AutoCad software. The first step is to resize the segment. From the beginning of the project, we had a map of the real estate maps of Miskolc landscapes, with real dimensions and coordinates. Within Arcmap, on this layer, we selected arbitrary plot boundaries or object parts that can be identified on both maps, and then described the exact data in the original scale. Using the "scale" tool, we enlarged the polylines in AutoCad software to the right size, so the base map was scaled to the real city dimension. The next step was to get the correct geographic coordinates by selecting a point on the plot map. In Hungary, the EOV projection system is generally used, so it is important that our map also exists on the basis of this representation, as it can vary or distort the scale of two different projections. We applied the „move” tool to move the base map to its correct location using the measured coordinates.

After transferring the layers to ArcGIS, the layer has to be transformed into an EOV projection system. In order to gain access to any specific changes to the map section, we had to convert the map to the programs own format with the "Feature class to feature class" tool, so the layer would be editable on the interface. It's important not to keep unnecessary elements (points, polygons and annotation) as part of the map, so we only convert the polylines we need with the device to mark buildings, land borders, and roads. After filtering all of this out of the segment, we reduced it further with sorting out one of the twelve "colors" (which attribute came from the original 
AutoCAD layout) to get rid of the unnecessary elements. Although we used the correct coordinates in AutoCad software, there were minor discrepancies between maps. Tasks include converting data from one coordinate system to another, correcting geometric distortions, adjusting elements at the edge of a layer to adjacent layers, and comply attributes between layers. Because spatial adjustment works within an editing session, we implemented existing editing functions using the snapping tool. We performed vector georeferencing, which is a procedure for assigning defective points, units to polylines representing building elements that correspond to accurate location data. We sorted out the buildings based on the OBJECT ID in the attribute table: the elements of the cadastral base map have a lower ID number and the added content has a higher number, in the order they were created. Once the 84 sections were completed, we stitched it with the "merge" tool. We transformed the polylines into polygons, then filled in the attribute table of the polygons representing the streets with street names using OpenStreetMap. We generated a unique building ID for each building, and assigned the name of the street closest to the object with the "Spatial Join" tool. We also added the house number to the attribute table for each object manually.

Database of companies in the city (including company name, address, industry, year of registration, annual net sales, last headcount and tax number) was obtained from BISNODE (www.partnerradar.hu), „E-cégjegyzék” (www.e-cegjegyzek.hu) and „céginformáció” (www.ceginformacio.hu) open source websites. The classification of the subsector, sector and national economy was based on the NACE structure.

\section{Eger}

In the case of Eger, we already had a cadastral base map which we had to complete. The base map contained the following elements:

- Land Parcels from real estate cadastre

- Buildings from a real estate cadastre

- Roads-line layer

- Borders of the districts-line layer

We also created another database in excel, which contained the ventures of Eger. The elements of this database are the name of the company, the main activity on class/group/sector/section level, the latest data to the headcount of employees (if available), sales returns (if available) the headquarters/branches of the company (at the investigated settlements) and the address of the headquarters and branches. In the case of Eger, we collected the ventures data partly from online open sources, such as https://www.e-cegjegyzek.hu/ and https://www.ceginformacio.hu/, and partly from https://www.bisnode.hu/.

For visualization, when multiple companies were in a building, the polygon representing the building was divided into pieces. In this case we manually cut 
of buildings along parallel lines (Cut Polygons Tool, parallel), also dividing the individual building identifier code, for example: Eger_24110//1, Eger_24110//2. In the divided buildings, the companies which are working in the same section, located next to each other. To link buildings, we generated a unique building ID number for each building, so when we had to split the buildings, we also subdivided that ID with a "//" which marks the technical character of the divided polygon. The building ID is a technical number, which we use for the concrete spatial identification of the buildings. The buildings haven't got an official identifier number, like in the case of parcels. Hence buildings on the same parcel don't have individual street numbers. Accordingly, we have generated the building identifier using field calculator in the following method: name of the settlement + underscore + five-digit sequential number (Object_ID). If the O_ID doesn't reach the five-digit length, the first number characters will be "0" characters. For example, in Eger the Object_ID of the first chosen building: Eger_00001. After verifying that every data has a match we joined the excel database to the buildings-polygon layer by matching the addresses with the unique ID's and then we joined of the company database based on unique building ID. We created a color ramp for the economic sections, using the most associative colors for each section.

The result was a map where every single venture was displayed with the color of their section. We displayed the number of companies on city district level too because, because the most versatile and best-used method of thematic maps showing statistical data is applying charts to maps.

\section{Results}

After completing the databases, we created a building-level economic map for each district as shown on figure 2, using the color ramp we made for symbols of economic sections. This map may give accurate spatial data for the location of the companies, but it's less informative according to the overall venture presence and the other qualities of the companies. We displayed the data from a different approach: figure 3 shows the distribution of the ventures numbers according to their economic activity on district level. 


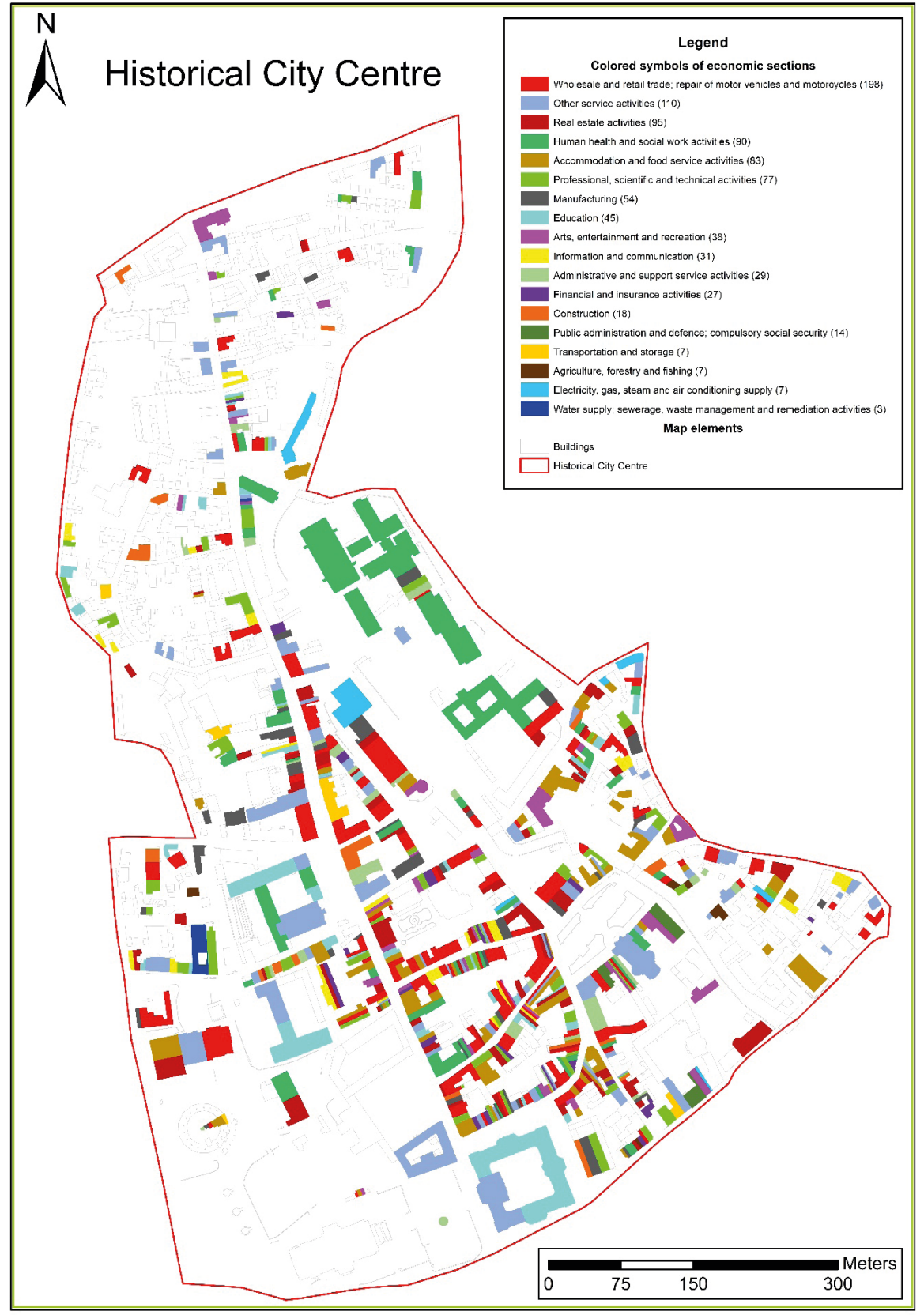

1. figure The economic map of Eger's Historic City Centre according to the activity of the ventures 


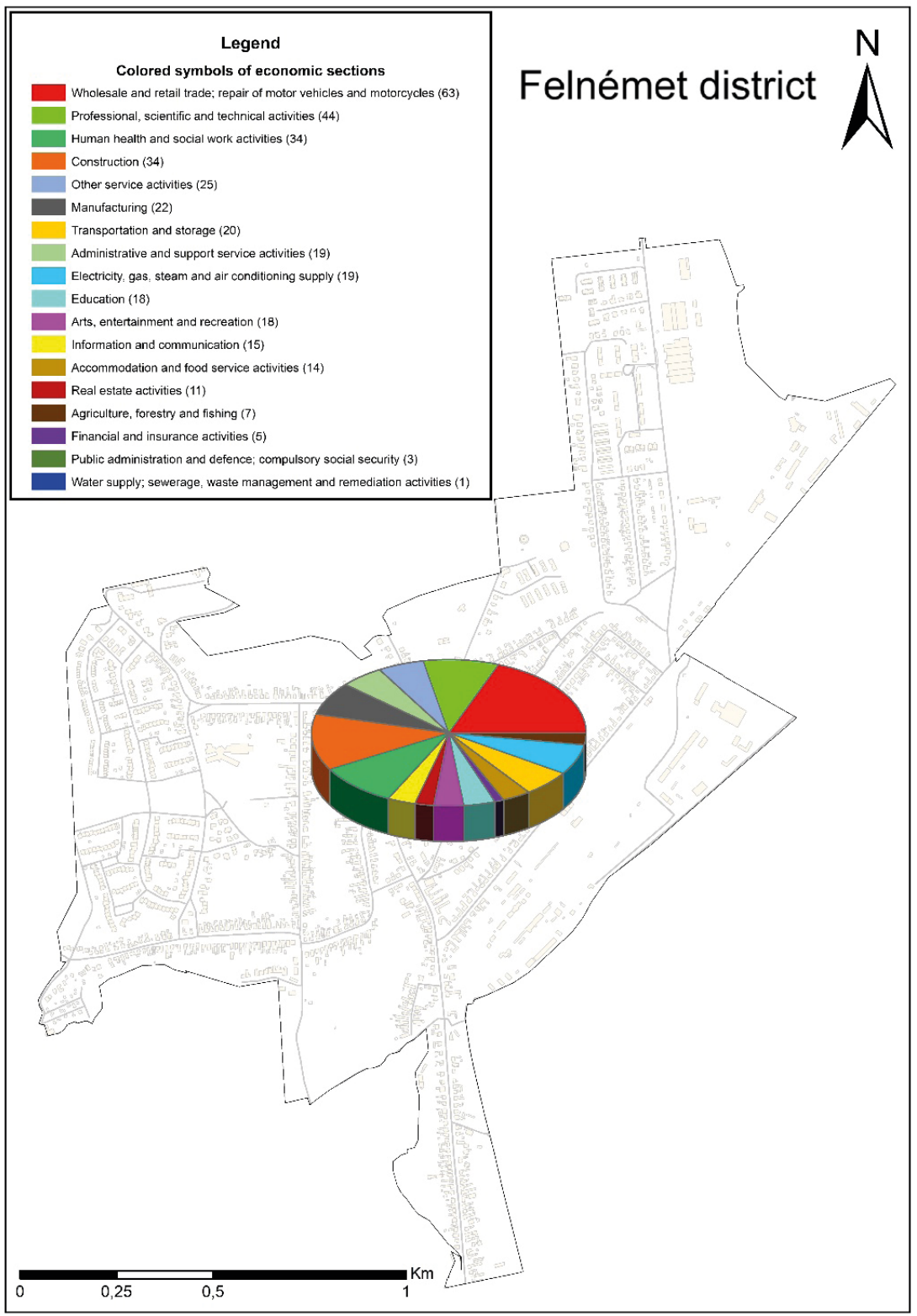

2. figure The number of ventures in sections of Felnémet district displayed on pie chart 


\section{Conclusion:}

In the further research, some of the aforementioned methodologies will be neglected due to their time-consuming nature. The visualization created by building-level parallel cutting needs too much manual work, that are more difficult to apply than economic spatial modeling of larger cities. Instead we will create the databases and maps in district level. This kind of presentation is almost equally eloquent, although the way it is illustrated is not as accurate, but the nodes of companies operating in different sectors of the economy are just as easy to identify. In the upcoming period of research, it is more expedient to purchase a complete database of company data in a ready-to-buy form, instead of free interfaces, to save time and obtain a more complete data set.

\section{References}

[1.] Lénárt Csaba, Tamás János, Juhász Csaba, Cifer Attila, Szabó Attila (2003): Általános Térinformatikai alapok, Kiadó: Miskolci Egyetem

[2.] Nagyváradi László, Pirkhoffer Ervin (2008): A modern geográfia kihívása: A térinformatika önkormányzati alkalmazásának új lehetőségei Kozármisleny példáján, Kiadó: Földrajzi értesítő

[3.] Sárközy F. (2004): Térinformatikai Oktató Anyag BME Általános- és Felsgeodéziai Tanszék, (elektronikus tankönyv)

[4.] Huiyue Wang, Dongjie Chen, Huabo Duan, Fengfu Yin, Yongning Niu (2019): Characterizing urban building metabolism with a 4D-GIS model: A case study in China, Kiadó: Journal of Cleaner Production https://doi.org/10.1016/j.jclepro.2019.04.341

[5.] Zoltán Utasi - Balázs Hegyi - Sándor Molják - Csaba Ruszkai (2019): Integrated cadastral and technical databases. In.: Geographia Napocensis 2/2019; Academia Romana - Filiala Cluj Colectivul de Geografie; Cluj Napoca 